\title{
Policy options for improved integration of domestic timber markets under the voluntary partnership agreement (VPA) regime
}

\section{Synthesis from lessons learned in Cameroon, the Democratic Republic of the Congo, Ecuador, Gabon and Indonesia}

\author{
Paolo Omar Cerutti, Yustina Artati, Ahmad Dermawan, Alice Kelly, Guillaume Lescuyer, Elena Mejía, \\ Krystof Obidzinski, Pablo Pacheco, Louis Putzel, Raphael Tsanga and Andrew Wardell
}

\section{Key points}

- The Forest Law Enforcement, Governance and Trade (FLEGT) Action Plan, launched in 2003, is the European Union's (EU) response to the global fight against illegal logging. In particular, FLEGT aims at reducing trade in illegal timber between the EU and timber producer partner countries.

- FLEGT operates through two major instruments: bilateral trade agreements — known as voluntary partnership agreements (VPAs) — that are signed with willing producer countries, and the European Union Timber Regulation (EUTR), which came into force in March 2013. The EUTR mandates EU importers to exert due diligence in their sourcing of timber from abroad to exclude illegal supplies.

- To date, six countries have signed VPAs. Among them, five have committed to apply VPA provisions regarding legality verification not only to timber imported to Europe, but also to timber traded on the domestic market in signatory producer countries. This means that timber harvested and traded on the domestic market will be regulated by national VPA licensing schemes (the so-called Timber Legality Assurance System, [TLAS]).

- Cameroon, the Democratic Republic of the Congo (DRC), Ecuador and Indonesia are characterized by a large, vibrant and largely informal domestic timber sector, which supports the livelihoods of hundreds of thousands of local forest users including small-scale farmers, indigenous communities, chainsaw millers, traders and service providers such as transporters. The domestic sector in Gabon is less significant due to the country's small population and the concentration of activities in the capital. In most countries, employment in the informal sector is comparable to or higher than the formal industrial timber sector. The estimated number of informal jobs provided by the sector varies greatly among countries, from about 45,000 in Cameroon to about 1.5 million in Indonesia.

- In all countries studied, the domestic timber sector is characterized by the activities of smallholders, chainsaw millers and traders, who rarely own a legal harvesting permit and extract and process small quantities of timber with chain or mobile saws. The resulting low-quality timber is traded in domestic markets or across the borders of neighboring countries, with little formal taxation. Research results indicate, however, that as the product moves along the production chain, 5-15\% of the total costs incurred by informal operators are paid in bribes to representatives of ministries, local police, the military and customs officials.

- By agreeing to include the domestic sector as an integral part of their TLAS, producer countries are committing to undertake broad governance reforms of the entire forestry sector. Implicitly, such reforms entail formalization of the domestic sector through monitoring, control and verification.

- In the countries of the Congo Basin and in Indonesia, such reforms will require the redrafting of current legal frameworks, which are designed around industrial large-scale export-oriented forestry operations, conducted by politically powerful companies with logging concessions. In all countries, existing laws are not structured to sustain a healthy, small-scale, domestic timber market. Research findings indicate a need to improve and simplify access to the resource; to develop and adopt specific fiscal regimes for the domestic timber sector (e.g. royalty rates, processing, transport and marketing levies); to improve access to credit on favorable terms for small-scale operators; to create incentives to comply with the law; and to improve flows of information to small-scale operators.

- In countries that have already signed a VPA (Cameroon and Indonesia) or continue to negotiate them (DRC and Gabon), local forest users and traders have been largely absent from in-country VPA negotiations. This reflects their large numbers, distribution over a vast territory and poor organizational capacity, as well as the tensions that often exist between the central governments' stated willingness to formalize them, and the rent-seeking behavior of decentralized officials. Hence, before reforms are initiated, 
specific channels of communication need to be set up for chainsaw millers and traders to discuss their needs, customary governance systems, and the potential challenges and expectations of formalization.

- Similarly, results indicate that the degree of governmental inclusiveness that characterized the initial VPA discussions tends to decrease over time, as political momentum is lost. Government agencies other than forestry and environment ministries may be excluded from the final phases of implementation, when legal reforms will have to be adopted. This could entail enforcement failures, as agencies may be unwilling to enforce rules they did not contribute to creating. The engagement of other ministries, in particular ministries of finance, is necessary for a meaningful national discussion of the financial implications of a functional TLAS for operators, especially small-scale ones. Such discussions have not yet taken place. This could engender implementation failures, if the advantages of the system are not evaluated from inception against the disadvantages (e.g. costs to operators).

- Formalization processes come with both benefits and risks, which require ongoing assessment, monitoring and mitigation. Case studies of formalization conducted in other natural resource sectors indicate that even well-intentioned processes can lead to exclusion, criminalization, barriers to entry and elite capture. These could disproportionally and negatively affect smallholders and small-scale operators, and lead to negative environmental impacts. If well conceived and monitored, formalization could increase transparency and clarity of users' rights, reduce conflict and improve working conditions and local economic benefits.

\section{Introduction}

In 2003, the EU launched the FLEGT process to curb illegal logging and limit the amount of illegal timber entering the EU. The FLEGT approach aims to foster sustainable forestry practices, improve forest governance in timber producing countries and fight poverty. The key instruments to achieve this goal are VPAs and the EUTR. In essence, VPAs are trade agreements through which the EU provides technical assistance and training to help build improved TLASs and ensure effective means of legality verification in partner producer countries. The EUTR mandates due diligence of all importing companies over the legality of timber upon 'first placement' on the EU market.

To date, six VPAs have been ratified by the EU with Cameroon, Central African Republic, Republic of the Congo, Ghana, Indonesia and Liberia. Furthermore, a number of countries in Africa, Asia and Latin America have started negotiations (see http://www.euflegt.efi.int/vpa-countries). Although implementation of the VPAs is taking longer than initially expected, there remains optimism that VPAs, used in conjunction with the EUTR, will help curb illegal logging in partner countries and reduce placement of illegally traded timber on the EU market.

Once fully operational, it is expected that the legality assurance systems and capacity-building programs will not only be effective in safeguarding the integrity of direct timber trade, but also will make broader contributions to sustainable forest management, better forest governance and improved livelihoods in producer countries. It is anticipated that these actions will help to reduce market inequalities between the small-scale domestic sector and the large-scale industrial export-oriented sector.

Currently, national policies do not provide an adequate response to the challenges associated with the growth of the domestic sector, its impact on forests, attendant legislation and the direct or indirect links to exports. Nevertheless, many VPA countries (e.g. Cameroon, Republic of the Congo,
Ghana, Indonesia and Liberia) have extended the scope of the TLAS to include all wood produced and traded domestically. As a result, the FLEGT process is positioned to increase attention on the governance of the domestic timber sector, by offering policy measures (to be implemented through reforms of legal frameworks), technical innovations (through the deployment of TLASs), capacity building of different actors (e.g. skills upgrading and ad hoc funding to local civil society organizations to improve independent verification and monitoring capacities, or to enhance the capacity of the national and regional media to cover forestry-related issues), and public consultations.

\section{Pro-formal}

Between 2010 and 2013, CIFOR implemented Pro-Formal, an EU-funded project to analyze policy and regulatory options to recognize and better integrate the domestic timber sector in tropical countries. The project was conducted in three regions (Southeast Asia, sub-Saharan Africa and Latin America), and five countries (Cameroon, DRC, Ecuador, Gabon and Indonesia). The results show that the volumes of timber harvested by chainsaw millers and the financial contribution of the sector to both rural and urban areas are substantial, notably when compared to the respective contributions of the industrial forestry sector (Table 1).

Each country studied has its own history and conditions, which call for specific policy options in order to better integrate the domestic and regional timber sectors in the country's legal frameworks. Such county-specific policy options are discussed in a series of infobriefs available at www.cifor.org/pro-formal. This infobrief presents general policy suggestions that arise from a comparative analysis of all countries studied, as well as a set of studies conducted by the project on the formalization of natural resource access and trade (Cerutti and Lescuyer 2011; Lescuyer et al. 2011; Mejía and Pacheco 2013; Lescuyer et al. 2014; Putzel et al. 2014; Obidzinski et al. In press). 
Table 1: Key findings on informal and formal production of timber.

\begin{tabular}{|c|c|c|c|c|c|}
\hline & CMR & GAB & DRC & IND & ECU \\
\hline $\begin{array}{l}\text { Annual domestic } \\
\text { consumption } \\
\text { from informal } \\
\text { chainsaw milling } \\
(\text { sawnwood, } 000 \\
\left.\mathrm{m}^{3}\right)^{\mathrm{a}}\end{array}$ & 662 & 50 & 1,024 & $1,408^{b}$ & $60-76^{c}$ \\
\hline $\begin{array}{l}\text { Estimated } \\
\text { informal jobs } \\
(000)\end{array}$ & 45 & 1 & 25 & $1,500^{d}$ & $3.6^{\mathrm{e}}$ \\
\hline $\begin{array}{l}\text { Contribution to } \\
\text { local economies } \\
\text { (million } € \text { ) }\end{array}$ & 32 & 1.6 & $34^{f}$ & $63^{9}$ & $9^{h}$ \\
\hline $\begin{array}{l}\text { Profit per } \mathrm{m}^{3} \\
\text { harvested }\left(€ / \mathrm{m}^{3}\right. \\
\text { RWE) }\end{array}$ & 5 & 6 & $4-24$ & $85^{i}$ & 7-183 \\
\hline $\begin{array}{l}\text { Annual formal } \\
\text { production/ } \\
\text { export (sawn } \\
\text { wood, } 000 \mathrm{~m}^{3} \text { ) }\end{array}$ & 360 & 150 & 36 & 1,199j & $170^{k}$ \\
\hline $\begin{array}{l}\text { Annual forest } \\
\text { taxes paid (formal } \\
\text { sector, million } €)^{\prime}\end{array}$ & 29.3 & 53 & $58^{m}$ & $227.2^{n}$ & $6.4^{\circ}$ \\
\hline
\end{tabular}

$\mathrm{CMR}=$ Cameroon, $\mathrm{DRC}=$ Democratic Republic of the Congo, $\mathrm{ECU}=$ Ecuador, $\mathrm{GAB}=\mathrm{Gabon}, \mathrm{IND}=$ Indonesia, $\mathrm{RWE}=$ roundwood equivalent.

a This excludes timber sold on the domestic market but sourced from industrial sawmills.

b Central Statistical Agency (2010 data).

c This value is based on the $24-31 \%$ estimate of informal timber related to native forests.

d Central Statistical Agency (2010). Data includes the timber industry, paper and paper products, and furniture. If only timber and the timber industry are included, such number could be about half a million workers.

e Includes chain-saw operators and workers in processing centers.

f Rural population only.

g Central Statistical Agency (2010 data). Contribution to local economy is in terms of worker compensation. It is assumed that half of worker compensation under the Standard Industrial Classification (ISIC 16) goes to workers in the sawn wood industry.

h Smallholders'income.

i Central Statistical Agency (2010 data). Calculated as half of the industrial profit of ISIC 16 divided by sawnwood production.

j Central Statistical Agency (2010).

k FAOSTAT (2012).

I Where not indicated otherwise, these include area, stumpage, sawmill entry and export fees.

m Area and export fees, Taxe de deboisement.

n Ministry of Forestry Indonesia.

- Authors' estimates based on total production of sawnwood based on Ministry of Environment of Ecuador.

\section{Policy recommendations}

\section{Sustain political inclusiveness}

Given delays in VPA implementation in most signatory

countries, expectations are high, resulting in a recent tendency to rush the issuance of FLEGT licenses. However, accelerated action may jeopardize the degree of inclusiveness that has so far positively characterized the VPA process in all countries (Bollen and Ozinga 2013). Results indicate a decrease in the level of inclusion of intersectoral government agencies that characterized the initial VPA discussions. Enforcement failures may ensue if such agencies are excluded during the final phases of implementation, when forest legal reforms are adopted. Ministries may hesitate or even plainly avoid enforcing rules they did not contribute to designing.

Of particular concern is the exclusion of ministries, including those overseeing lands, agriculture, rural development and labor, which could adopt regulations facilitating the formalization of smallholders and chainsaw millers. This could include changes in access or use rights in smallholder agriculture-forest mosaic landscapes from which the majority of informal timber is harvested.

To mitigate this risk, resources will have to be committed to convening more inclusive round tables. However, VPA negotiators will have to strike a delicate balance to obviate the risk of opening up the debate with other ministries that may, for instance, shift the discourse away from forest laws and into other legal reforms, such as basic agrarian or land tenure laws. This would risk lengthening the VPA-related reform process by several years if not decades.

\section{Promote inclusion of small-scale operators}

All formalization case studies undertaken by the Pro-Formal project highlighted the risk of exclusion, loss of rights and possible conflicts, especially of marginalized and less powerful groups. While promoting reforms, the VPA implementation process should pay particular attention to the risk of exclusion of smallholders, chainsaw millers and domestic timber traders. In VPA countries, a great lobbying advantage is held by industrial, large- to medium-scale logging companies that have forged strong direct links with powerful actors, notably with ministries of forests. It should not be assumed that just because chainsaw milling and domestic timber markets are mentioned in the VPAs, large-scale operators will not exert their lobbying power during implementation. This could be done to gain as many advantages as possible from reform, notably under the banner of their current 'legal' position versus the criminalized 'illegal' operators.

Pro-Formal results indicate that the practical steps to best promote inclusion will need to include a mix of simplified regulations, more secure tenure rights, increased access to credit for sustainable forest management, better information on markets, and increased efforts by governments, donors and the private sector to help smallholders and chainsaw millers build social capital. In particular, case studies on formalization show that smallholders, chainsaw millers and domestic traders could achieve greater authority through representative institutions. Examples of achievements in terms of collective action that meets the higher costs of formalization already exist and show promising positive impacts. For instance, recent experience in Jepara, Indonesia, shows that small and medium enterprise (SME) operators have been able to pool resources to meet the high cost of securing Timber Legality Verification System (Sistem Verifikasi Legalitas Kayu, SVLK) licenses (Purnomo et al. 2014). However, overall progress with group certification remains slow. 


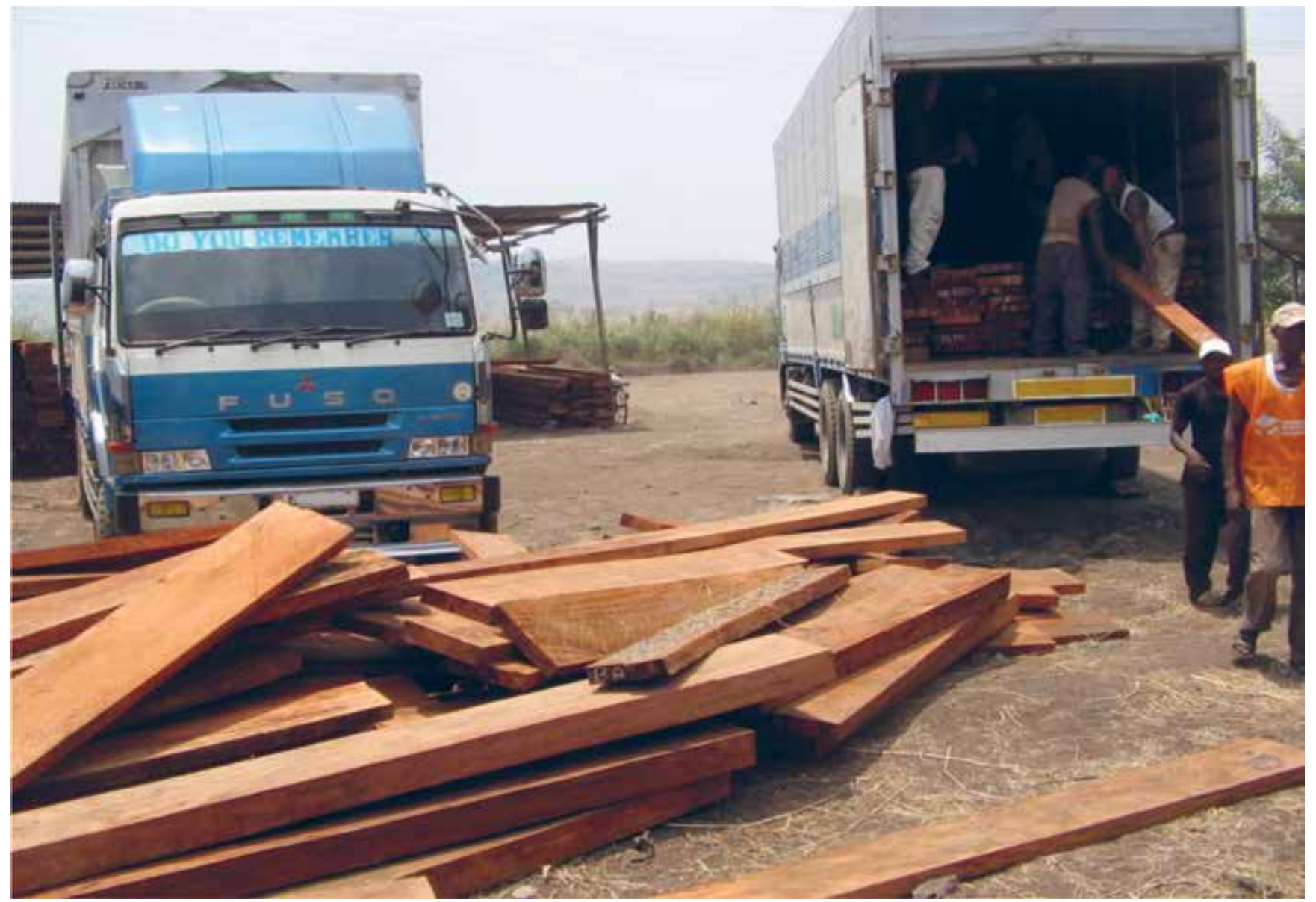

Loading of sawn wood at a border crossing, DRC.

Photo by Francois Biloko, Reseau CREF, Goma, DRC

\section{Plan verification systems with a focus on the demand side}

The biggest challenge to the current efforts in planning and implementing traceability systems - in all Pro-Formal countries and beyond - is the large number of informal operators and operations. While it is of course important to monitor activities where the resource is harvested, in terms of timely and more effective implementation of the FLEGT Action Plan, monitoring large swathes of forest is unlikely to be a cost effective and efficient solution. As all country case studies show, the vast majority of harvested timber ends up in large markets or depots in the main cities. Without neglecting the ecological dimension of informal timber harvesting — to which concerned governments should devote more attention (Robiglio et al. 2013) - the current situation suggests that greater efforts need to be invested in monitoring downstream activities in the value chain (e.g. markets, depots, sawmills, industries). The latter should also bear part of the technical and financial responsibility for formalizing the operations of their suppliers, as they represent an easier 'target' for control by governments limited by both human and financial resources.

Concurrently, support could be provided (in the form of tax rebates, market access or other incentives) to individual, small or large-scale enterprises that decide to invest in legal domestic or regional supply chains.

\section{Simplify rules, decrease transaction costs and decentralize authority where feasible}

A major lesson learned in Pro-Formal countries is that, for both historical and political reasons, the types of permits and permitissuing procedures are far too complex for current users to apply for or comply with. Thus, it is suggested that a simplification of the types of permits and issuing procedures is undertaken as part of the legal reforms.

Simplification should aim at improving transparency in permit issuing procedures, monitoring of domestic timber value chains and access to information on timber prices. Simplification, however, should also necessarily involve a reduction in transaction costs for smallholders and chainsaw millers. It is not worth investing in online and mobile communication schemes for issuing permits, if the costs of those permits remain too high for smallholders and chainsaw millers.

One possible means to reduce costs is the decentralization of key granting functions and responsibilities. This may include permit issuing, access to credit through public funding sources, technical advice and extension services, and access to improved planting material, among others. However, it is also important to consider one key caveat. Experience from several countries (Indonesia and Ghana are both well documented) suggests that processes of decentralization have often been associated with increases 
in informal forest exploitation and higher net annual rates of deforestation, as local authorities try to increase local revenues (e.g. Batterbury and Fernando 2006). Pro-Formal findings have also confirmed the continued problem of local elite capture, which must be considered if, and when, devising decentralized permit issuing procedures.

\section{Adopt innovative taxation schemes and incentives}

Any process of formalization must entail a greater role for the ministries of finance to set up taxation schemes that will consider the particular nature of the informal timber sector. This will be especially true during the inception phase of reforms, when proposed schemes will have to include fiscal incentives that motivate informal operators to join the formal sector. For instance, ministries of finance - if meaningfully included in VPA negotiations by ministries of forests - could suggest, adopt, implement and monitor tax rebates, 'zero VAT' or 'one-stopinvestment window' schemes, or premiums to State agents following seizures of illegal timber.

Innovative financial schemes, however, should only be adopted after the estimated costs of the TLAS implementation have been evaluated for both large- and small-scale operators. Once the likely costs of TLAS implementation and the potential impacts of new incentives have been estimated, VPA negotiators will need to discuss a roadmap for operators (largeas well as small-scale) to meet the future VPA compliance requirements. To date, very few VPA countries have thoroughly discussed the financial implications for operators, especially small-scale ones, of a functional TLAS. Once the likely costs of TLAS are estimated, incentives will have to be introduced to assist individual operators and SMEs in meeting them (Eba'a Atyi et al. 2013).

Incentives should also aim at bringing operators within the realm of legality while increasing their recovery and processing capacities to make better use of the resource. Fiscal and financial incentives seem the easiest way to try and reduce wastage. For instance, future formal tax rebates could be linked to investments in better saw mills, while the technical knowledge of ministries of forests on resource abundance, regeneration and management must be fully harnessed, to avoid a rapid 'legal' depletion of resources.

Another relatively easy-to-implement incentive could be the adoption, in partner countries, of public procurement policies requiring all public contracts to be supplied with locally produced legal timber. This could provide the necessary initial incentive for local operators to seek formal harvesting permits, as well as meet the higher cost of the formal procedures, to be rewarded by the higher price they could obtain in a legal public market.

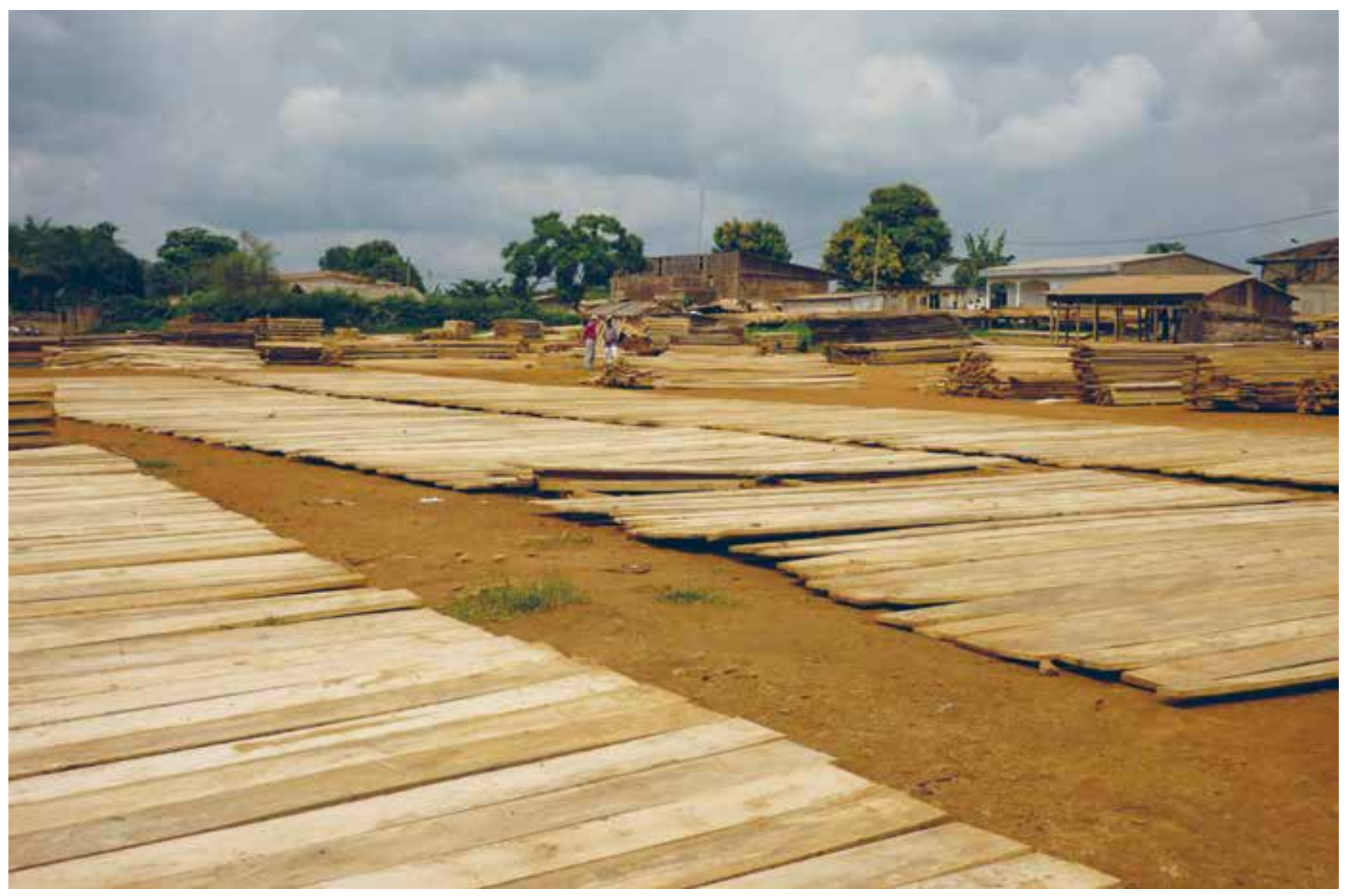

Sawn wood ready to be transported at a train station, Cameroon.

Photo by Edouard Essiane, CIFOR 
In order to bear positive impacts, most incentivizing schemes will have to go hand-in-hand with anti-corruption efforts.

\section{Support law enforcement and anti-corruption efforts}

Simplification and legal reform are just one side of the coin. On the other side, there remains a strong need for effective law enforcement. As with other reforms, this should not be exclusively linked to forestry ministries, but it should include efforts to create an effective judiciary, as well as to adopt targeted anti-corruption measures.

A well-conceived TLAS and improved transparency could help eliminate some potential key nodes along the production chain where corrupt transactions can occur. However, even the best of systems can be circumvented. This is especially true when the elimination of long-established behavior will mean changing the behavior of government officials, who stand to experience financial losses, notably from the formalization of smallholders and chainsaw millers. For such a change, TLAS implementation must be coupled with clear and sustained anti-corruption efforts led by the presidency or prime minister's office rather than by specific ministries (e.g. forests and environment)

\section{Monitor enforcement of new rules}

While law enforcement has a fundamental role to play in the deployment of TLAS, monitoring of rules to ensure equitable and consistent enforcement is needed to avoid a culture of impunity that would undermine the system. This means that a scalar approach to enforcement might be advisable, with the 'weakest' parts of the sector, notably current informal operators, being granted a grace period of learning before implementing and fully enforcing any new rules.

Rules must be fair and without disproportionate effects on any particular stakeholder group. Nevertheless, most countries have a huge gap in the capacities of informal operators to influence and abide by the law. If the relatively short-term VPA deadlines cannot be met - as Pro-Formal findings indicate — an initial via negativa approach could be preferred. Negotiators could initially guarantee that no informal timber would enter the TLAS, instead of trying to include all operators and their current practices into the TLAS before FLEGT licenses are delivered. If FLEGT licenses are to appear anytime soon on the EU market, this could be the least harmful option for small-scale operators and their livelihoods, as opposed to a forced adaptation to policies that did not sufficiently take into account their perspectives and economic needs.

\section{Consider transboundary issues}

Approaches to formalization should be developed in a manner that addresses the complexities of regulation and enforcement across transboundary landscapes. Historical data coupled with the study results indicate that national and regional timber markets have been growing steadily over the last decade. Available financial and demographic data indicate that such trends will continue for many years to come. Current informal timber produced by smallholders and chainsaw millers contributes significantly to these growing markets. Thus, all reforms aimed at formalizing the timber sector should be conceived with an extra-national focus, with the possible inclusion of regional and international platforms and institutions (e.g. the Experts Group on
Illegal Logging and Associated Trade (EGILAT) in the Asia-Pacific Region, the Economic Community of Central African States, the East African Community in sub-Saharan Africa, the Andean Community, or the Amazon Cooperation Treaty Organization in Latin America)

Where needed, legal frameworks should be adapted to include the possibility for smallholders and small-scale timber traders to export their production. This is currently forbidden in many VPA countries, but it could allow small-scale operators and governments to seize market opportunities with direct benefits for their livelihoods and State revenues. This, in turn, would encourage the changes needed to enter the legal market. Incentives could also be adopted, for instance by initially creating a system of export quotas (normally fetching higher prices) for compliant small-scale operators.

\section{Looking ahead}

The signing and ongoing implementation of VPAs in six countries, together with negotiations and preparation in many others, is a significant achievement of the FLEGT process. This is even more so the case against the backdrop of (1) the continuing global restructuring (and new geographies) of the tropical timber trade, (2) the emergence of other (dominant and often competing) forest sector policy agendas (notably REDD+), and (3) new initiatives (e.g. the Lacey Act and Australia's illegal logging law and regulations) and negotiating platforms on similar issues (e.g. EGILAT in the Asia-Pacific region, the Central African Forest Commission (Commission des Forêts d'Afrique Centrale, (OMIFAC) in the Congo basin, and the Southern African Development Community (SADC) in Southern Africa).

As far as domestic timber markets and small-scale operators are concerned, new policy options and proposed legal reforms need to be put to the test in select countries, or specific regions within countries, building on clear political commitments to do so in VPA (and non-VPA) countries, and where there is a demonstrable track record of existing forest sector governance reforms. The current prolonged implementation phase in most VPA countries remains an optimal testing ground for several proposed options on the domestic timber sector. There is scope to learn from initiatives in non-VPA countries, mainly from Latin America, where significant efforts have been implemented to improve forestry governance, including the institutions for supporting forest management and more developed systems for monitoring legal compliance.

\section{References}

Batterbury SPJ and Fernando JL. 2006. Rescaling governance and the impacts of political and environmental decentralization: An introduction. World Development 34(11):1851-96.

Bollen A and Ozinga S. 2013. Improving Forest Governance: A Comparison of FLEGTVPAs and their Impact. Brussels, Belgium and Moreton-in-Marsh, UK: FERN.

Cerutti PO and Lescuyer G. 2011. The domestic market for small-scale chainsaw milling in Cameroon: Present situation, opportunities and challenges. Occasional Paper 61. Bogor, Indonesia: Center for International Forestry Research. [French version also available: Cerutti PO and Lescuyer G. 2011. Le marché domestique du sciage artisanal au Cameroun: État 
des lieux, opportunités et défis. Occasional Paper 65. Bogor, Indonesia: Center for International Forestry Research.]

Eba'a Atyi R, Assembe Mvondo S, Lescuyer G and Cerutti PO. 2013. Impacts of international timber procurement policies on central Africa's forestry sector: The case of Cameroon. Forest Policy and Economics 32:40-8.

Lescuyer G, Cerutti PO, Ndotit Manguiengha S and Bilogo bi Ndong L. 2011. The domestic market for small-scale chainsaw milling in Gabon: Present situation, opportunities and challenges. Occasional Paper 65. Bogor, Indonesia: Center for International Forestry Research. [French version also available: Lescuyer G, Cerutti PO, Ndotit Manguiengha S and Bilogo bi Ndong L. 2011. Le marché domestique du sciage artisanal a Libreville, Gabon: État des lieux, opportunités et défis. Occasional Paper 63. Bogor, Indonesia: Center for International Forestry Research.]

Lescuyer G, Cerutti PO, Tshimpanga P, Biloko F, Adebu-Abdala B, Tsanga R, Yembe-Yembe RI and Essiane-Mendoula E. 2014. The domestic market for small-scale chainsaw milling in the Democratic Republic of Congo: Present situation, opportunities and challenges. Occasional Paper 112. Bogor, Indonesia: Center for International Forestry Research. [French version also available: Lescuyer G, Cerutti PO, Tshimpanga P, Biloko F, Adebu-Abdala B, Tsanga R, Yembe-Yembe RI and EssianeMendoula E. 2014. Le marché domestique du sciage artisanal en République démocratique du Congo: État des lieux, opportunités, défis. Occasional Paper 110. Bogor, Indonesia: Center for International Forestry Research.]

Mejía E and Pacheco P. 2014. Forest use and timber markets in the Ecuadorian Amazon. Occasional Paper 111. Bogor, Indonesia: Center for International Forestry Research. [Spanish version also available: Mejía E and Pacheco P. 2013. Aprovechamiento forestal y mercados de la madera en la Amazonía Ecuatoriana. Occasional Paper 97. Bogor, Indonesia: Center for International Forestry Research.]
Obidzinski K, Dermawan A, Andrianto A, Komarudin H, Hernawan $D$ and Fripp E. In press. Timber legality verification system and the voluntary partnership agreement in Indonesia: The challenges of the small-scale forestry sector. Working Paper. Bogor, Indonesia: Center for International Forestry Research.

Purnomo H, Achdiawan R, Melati, Irawati RH, Sulthon, Shantiko B and Wardell A. 2014. Value-chain dynamics: Strengthening the institution of small-scale furniture producers to improve their value addition. Forests, Trees and Livelihoods 23(1-2):87-101.

Putzel L, Kelly A, Cerutti P and Artati Y. 2014. Formalization of natural resource access and trade: Insights from land tenure, mining, fisheries, and non-timber forest products. Bogor, Indonesia: Center for International Forestry Research.

Robiglio V, Lescuyer G and Cerutti PO. 2013. From farmers to loggers: The role of shifting cultivation landscapes in timber production in Cameroon. Small-Scale Forestry 12(1):67-85. doi: 10.1007/s11842-012-9205-3.

\section{Additional reading}

Kishor N and Lescuyer G. 2012. Controlling illegal logging in domestic and international markets by harnessing multi-level governance opportunities. International Journal of the Commons 6(2):255-70.

Putzel L, Kelly A, Cerutti PO and Artati Y. 2014. Formalization of natural resource access and trade: Insights from land tenure, mining, fisheries, and non-timber forest products. Bogor, Indonesia: Center for International Forestry Research.

Wit M, van Dam J, Cerutti PO, Lescuyer G, Kerrett R and Parker Mckeon J. 2011. Chainsaw milling: Supplier to local markets - A synthesis. In Wit M and van Dam J, eds. Chainsaw milling: Supplier to local markets. Wageningen, the Netherlands: Tropenbos International. VII-XXII. 
The EU-funded project Pro-Formal (EuropeAid/ENV/2010-242904/TPS) was implemented by the Center for International Forestry Research (CIFOR) in three regions (Southeast Asia, sub-Saharan Africa and Latin America) and five countries (Indonesia, Cameroon, the Democratic Republic of the Congo, Ecuador and Gabon) from July 2010 to December 2013. The project has been implemented with several key partners, and some outputs have already been disseminated through CIFOR's occasional papers, infobriefs, scientific journal articles and other web-based materials (available on the project website: www.cifor.org/pro-formal).

\begin{tabular}{|c|c|c|}
\hline CGIAR & $\begin{array}{l}\text { RESEARCH } \\
\text { PROGRAM ON } \\
\text { Forests, Trees and } \\
\text { Agroforestry }\end{array}$ & $\begin{array}{l}\text { This research was carried out by CIFOR as part of the CGIAR Research Program on Forests, Trees and } \\
\text { Agroforestry (CRP-FTA). This collaborative program aims to enhance the management and use of } \\
\text { forests, agroforestry and tree genetic resources across the landscape from forests to farms. CIFOR } \\
\text { leads CRP-FTA in partnership with Bioversity International, CATIE, CIRAD, the International Center for } \\
\text { Tropical Agriculture and the World Agroforestry Centre. }\end{array}$ \\
\hline
\end{tabular}

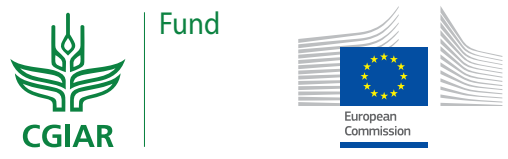

